\title{
Ecological Assessment of some Trace Elements Status in North Sinai
}

\author{
Osama M. Abdelmottaleb ${ }^{1}$, Sherif M. Ibrahim ${ }^{2}$ and Sherine Sh. Moured ${ }^{1}$
}

\begin{abstract}
The accumulation of trace elements in cropland soils poses a growing threat to sustainable agriculture development, and their dynamics throughout ecosystem components are among the most complicated issues to study and the most expensive to remediate. Hence, this paper proposes the forward mass balance modelling of any element as an approach to monitor and assess its status in cropland ecosystem, and to predict long-term results by computer simulations. Status of $\mathrm{Fe}, \mathrm{Mn}, \mathrm{Zn}, \mathrm{Cu}, \mathrm{Ni}, \mathrm{Mo}$ and $B$ in wheat and broad bean crops, irrigation water, fertilizers, and soil from North Sinai were investigated. The concentrations of the studied elements were within the permissible limits in most cases and beyond those limits in some cases. The seasonal input by irrigation and by fertilizers of each element was determined and the output by harvested crops and through leachate was estimated, all in units of g.ha ${ }^{-1}$ and $\mathrm{g.kg}^{-1}$. Also, the baseline values of the studied elements in the study area were reported for future reference as well as the mathematical description of the proposed approach. The quantitative profiling indicated that the current land use has increased soil content of $\mathrm{Mn}, \mathrm{Zn}$, Ni, Mo and $\mathrm{B}$. Irrigation water was identified as the cause of soil enrichment with $B$ and Mo; manure was the main source of $\mathrm{Ni}$ and $\mathrm{Zn}$; while both were the main sources of $\mathrm{Mn}$. The equilibrium between the input and the output was found to be the status of $\mathrm{Fe}$ and Cu. Analysis of the results showed the need to an interactive multi-criteria risk assessment framework in which considers all ecosystem components and the local conditions.
\end{abstract}

Keywords: Mass balance, Monte Carlo simulation, Potentially hazard elements, Trace elements cycle

\section{INTRODUCTION}

Modern agriculture targeting intensive production has started what may be called agricultural pollution i.e. wastes, emissions, and discharges arising from farming activities; such risk increases in cases like crop production involving low-quality irrigation water and improper management, causing the degradation of the eco-system (Bruinsma, 2003). Of the pollutants arising from intensification pesticides and trace elements are the most complicated to study (Rickert, 1993) and the most expensive to remediate (Van Deuren et al., 2002). Generally, the problems associated with trace metal contamination have been well highlighted in the literature; including health hazard to human, and

\footnotetext{
${ }^{1}$ Soil Chemistry and Physics Department, Desert Research Center,

Cairo, Egypt.

${ }^{2}$ Soil Fertility and Microbiology Department, Desert Research Center,

Cairo, Egypt

Received Novmber 15,2017, Accepted December 25, 2017
}

pollution to the natural resources (Jarup, 2003; Samia EL-Safy and El-Sayed, 2008; Moharem, 2016).

It is well known that the environmental fate of trace elements depends on the bioavailable content which usually has a wide variation. Trace elements in the environment may accumulate unnoticed to reach toxic levels, the soil environment is likely the most complex biological community. Soil contributes to a wide range of ecosystem services that are essential to the sustainable function of natural and managed ecosystems (Ragab et al. 2007, Filser et al. 2008).

Decisions on contaminated land management are based on various considerations, including plant toxicity and human health risks. Monitoring of soil quality and soil ecological assessment suffer from the absence of a commonly accepted framework that may act as a reference. From the technological perspective, the issues of wastewater treatment and remediation of trace elements contaminated soils can be solved (Terry and Banuelos 1999, Kurniawan et al. 2006, Pendergast and Hoek 2011). Applying such techniques efficiently so as to treat all the contaminated resources is currently not applicable and has many determinants. On the other hand, the impact of farm management system on both soil and crop product quality is a promising area for research. This area of work could provide applied recommendations on sustainable agricultural productivity, in addition to much scientific data that helps to deep understanding and modelling of different hazards processes in relation to impact on the ecosystem. Quantitative profiling of trace elements inputs to agricultural soils is necessary to determine the relative importance of different sources of every element (Nicholson et al. 2003, Mico et al. 2006, Alloway 2013); whereas the quantitative investigation of trace elements outputs seems less common in the literature (e.g. Schnoor 1996). However, studies on both, trace elements inputs to soil and the environmental fate of these elements, are rare. The accumulation of such data within an accepted framework can lead to an accurate mathematical description of elements cycle.

The environmental hazard of trace elements pollution has many aspects. The main interests of the present study are human exposure, phytotoxicity, soil 
quality, and impact of leachate on groundwater quality. The possible source, pathway and sensitive recipient of each element will be considered; the essential measurements will be characterized, along with the related factors that affect trace elements transfer, seeking for parts that can be manipulated in order to minimize the risk and achieve the sustainability.

\section{MATERIALS AND METHODS}

\section{Study area and field investigation}

The research plan considered an investigation area in Sahl El Tina, between latitude $31^{\circ} 05^{\prime} 12^{\prime \prime}$ to $30^{\circ} 50^{\prime} 20^{\prime \prime}$ and longitude $32^{\circ} 11^{\prime} 45^{\prime \prime}$ to $32^{\circ} 41^{\prime} 15^{\prime \prime}$, the northwestern part of Sinai, Egypt (Fig. 1). The study area is irrigated with water through El Salam Canal. The area of land planned for agriculture is $\approx 20000$ ha, of which $\approx 5000$ ha are planted with the selected crops i.e. wheat (Triticum aestivum) and broad bean (Vicia faba). Surface $(0-30 \mathrm{~cm})$ and subsurface $(30-60 \mathrm{~cm})$ soil samples were collected from the selected sites. Regular samples of irrigation water and fertilizers were collected and stored. The "shoot mass" and "grain yields" of the two crops were determined by the end of the growing season. Plant samples were also collected and separated into straw/grains and straw/seeds, washed by tap water, then by distilled water, dried at $70{ }^{\circ} \mathrm{C}$ and grounded using stainless steel mill to fine powder before storing for chemical analysis. The air-dried soil samples were crushed, ground, and passed through a mesh sieve (2 $\mathrm{mm}$ ) before storing for further analysis.

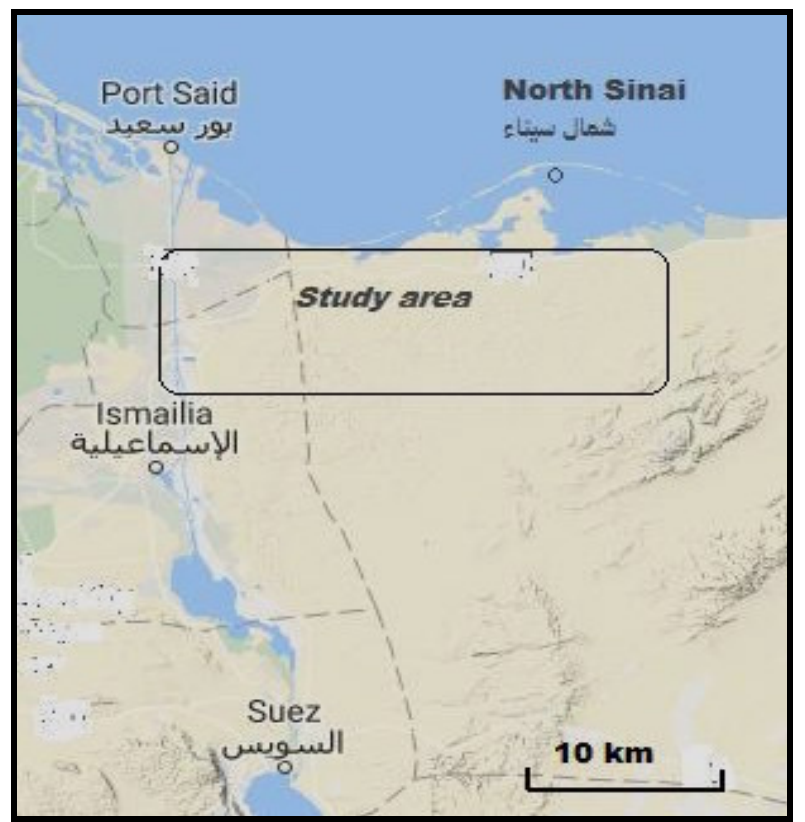

Fig. 1. Map showing the location of the study area

The configuration of the sampling locations was based on the conditioned Latin hypercube method (Minasny and McBratney 2006) using water quality and land use time as variables. Five subsections were identified. At each site, a number of samples were investigated. To predict the minimum number of soil samples required to estimate the average element concentration in the investigated environment, we employed the equation: $n=(\mathrm{ts} / \mathrm{e})^{2}$ (Avery and Burkhart 1994) and the results of previous studies on the same area (Hafez et al. 2008, El-Sisi 2015) where; $\mathrm{t}$ is the $\mathrm{t}$ statistic value selected for a given confidence level, $\mathrm{s}$ is the standard deviation, and $\mathrm{e}$ is the acceptable level of error or uncertainty. We assumed 100 degrees of freedom at $95 \%$ confidence level, the corresponding $\mathrm{t}$ value is 1.98 , the standard deviation values of soil content of $\mathrm{Mn}$ and $\mathrm{Zn}$ were 0.82 and 0.48 , respectively. For the sample mean to be within $\pm 0.5 \mathrm{mg} / \mathrm{kg}$ of the population mean, $\mathrm{n}$ values were found to be 11 and 4 , respectively. Accordingly, each site was represented by 11 soil samples and a corresponding number of plant samples. Irrigation water and fertilizers samples were systematically collected at every application during the investigated season.

\section{Laboratory work}

Particle size distribution was performed using the pipette method for assessing soil texture for fractions less than $2 \mathrm{~mm}$ (Gee and Bauder, 1986). Values of pH and electrical conductivity (EC) were measured in 1:2.5 soil-water suspension and supernatant, respectively as described by Page et al. (1982). Soil organic matter (OM) was determined using the procedure of Walkely and Black as outlined by Page et al. (1982). These characterizations are presented in Table 1.

The Fe, Mn, $\mathrm{Zn}, \mathrm{Cu}, \mathrm{Ni}, \mathrm{Mo}$ and B were extracted by $1 M \mathrm{NH}_{4} \mathrm{HCO}_{3}$ in $0.005 M$ DTPA adjusted to a $\mathrm{pH}$ of 7.6 (Soltanpour, 1991), and the concentrations of elements were measured using inductively coupled plasma optical emission spectroscopy (ICP-OES) as described by Varma (1991). Total elements contents of the soil were digested with aqua-regia $\left(\mathrm{HCl}: \mathrm{HNO}_{3}, 3: 1\right)$ as described by Page et al. (1982), and measured using ICP-OES. Irrigation water examination was carried out as recommended in Standard Methods for The Examination of Water and Wastewater (APHA 2005). Plant samples were wet digested using $\mathrm{H}_{2} \mathrm{SO}_{4}-\mathrm{H}_{2} \mathrm{O}_{2}$ mixture according to Wolf (1982) and fertilizers samples were digested using $\mathrm{HNO}_{3}, \mathrm{HCl}$, and $\mathrm{H}_{2} \mathrm{O}_{2}$ as described in USEPA Method 3050B (2016). The acid digest was analyzed for $\mathrm{Fe}, \mathrm{Mn}, \mathrm{Zn}, \mathrm{Cu}, \mathrm{Ni}, \mathrm{Mo}$ and $\mathrm{B}$ content using ICP-OES.

A leach test using an up-flow percolation column procedure was implemented in the laboratory to simulate the leaching behaviour of the element of interest. A $60 \mathrm{~cm}$ straight cylindrical column with an inner diameter of $5 \mathrm{~cm}$, filled with $1500 \mathrm{~g}$ air-dried soil, 
Table 1. Selected characteristics of the studied soil

\begin{tabular}{|c|c|c|c|c|c|c|c|c|c|}
\hline \multirow{2}{*}{$\begin{array}{l}\text { Site } \\
\text { No. }\end{array}$} & \multirow[t]{2}{*}{$\begin{array}{l}\text { Land use } \\
\text { time (year) }\end{array}$} & \multirow{2}{*}{$\begin{array}{l}\text { Soil depth } \\
\quad(\mathrm{cm})\end{array}$} & \multirow[t]{2}{*}{ pH } & \multirow{2}{*}{$\begin{array}{c}\text { EC } \\
(\mathrm{dS} / \mathrm{m})\end{array}$} & \multicolumn{3}{|c|}{$\begin{array}{c}\text { Particle size } \\
\text { distribution }(\%)\end{array}$} & \multirow[t]{2}{*}{ Texture class } & \multirow[t]{2}{*}{ OM \% } \\
\hline & & & & & Sand & Silt & Clay & & \\
\hline \multirow{2}{*}{1} & \multirow{2}{*}{$\approx 5$} & \multirow{2}{*}{$\begin{array}{c}0-30 \\
30-60\end{array}$} & 8.25 & 1.19 & 94.3 & 4.9 & 0.9 & Sand & 0.87 \\
\hline & & & 8.15 & 2.23 & 92.4 & 5.1 & 2.5 & Sand & 0.53 \\
\hline \multirow{2}{*}{2} & \multirow{2}{*}{$\approx 5$} & $0-30$ & 8.23 & 1.05 & 88.9 & 3.3 & 7.8 & Loamy sand & 0.91 \\
\hline & & $30-60$ & 8.41 & 2.18 & 95.0 & 3.6 & 1.5 & Sand & 0.36 \\
\hline \multirow{2}{*}{3} & \multirow{2}{*}{$\approx 10$} & $0-30$ & 8.12 & 2.66 & 36.1 & 39.4 & 24.5 & Loamy & 0.78 \\
\hline & & $30-60$ & 8.34 & 1.65 & 62.9 & 19.9 & 17.2 & Sandy loam & 0.47 \\
\hline \multirow{2}{*}{4} & \multirow{2}{*}{$\approx 10$} & $0-30$ & 8.25 & 2.55 & 55.2 & 18.9 & 25.9 & Sandy clay loam & 0.75 \\
\hline & & $30-60$ & 8.43 & 3.41 & 67.7 & 15.8 & 16.5 & Sandy loam & 0.69 \\
\hline \multirow{2}{*}{5} & \multirow{2}{*}{$\approx 10$} & $0-30$ & 8.65 & 3.60 & 57.6 & 16.1 & 26.3 & Sandy clay loam & 0.82 \\
\hline & & $30-60$ & 8.59 & 5.32 & 72.4 & 5.7 & 21.9 & Sandy clay loam & 0.71 \\
\hline \multicolumn{10}{|c|}{ Table 2. The concentrations of elements in soil leachate $\left(\mathrm{mg} \cdot \mathrm{L}^{-1}\right)$} \\
\hline Soil & No. & \multicolumn{2}{|c|}{ Mn } & $\mathbf{Z n}$ & \multicolumn{2}{|c|}{$\mathrm{Cu}$} & $\mathrm{Ni}$ & Mo & B \\
\hline \multicolumn{2}{|c|}{1} & \multicolumn{2}{|c|}{0.011} & 0.003 & \multicolumn{2}{|c|}{0.003} & 0.001 & 0.002 & 0.065 \\
\hline \multicolumn{2}{|c|}{2} & \multirow{2}{*}{\multicolumn{2}{|c|}{0.023}} & 0.007 & \multicolumn{2}{|c|}{0.003} & 0.001 & 0.002 & 0.014 \\
\hline \multicolumn{2}{|c|}{3} & & & 0.004 & \multicolumn{2}{|c|}{0.003} & 0.001 & 0.002 & 0.012 \\
\hline \multicolumn{2}{|c|}{4} & \multicolumn{2}{|c|}{0.027} & 0.008 & & & 0.002 & 0.003 & 0.013 \\
\hline \multicolumn{2}{|c|}{5} & \multicolumn{2}{|c|}{0.022} & 0.004 & 0.0 & & 0.001 & 0.007 & 0.011 \\
\hline $\mathrm{Mc}_{\mathrm{c}}$ & & 0.0 & & 0.005 & 0.0 & & 0.001 & 0.003 & 0.023 \\
\hline
\end{tabular}

a $1 \mathrm{~cm}$ layer of silica sand was used at the bottom and at the top of the column. $0.001 M$ calcium chloride solution was used with a flow rate of 0.6 L.h ${ }^{-1}$, entire solution volume was $5 \mathrm{~L}$ for each column to simulate field irrigation, five composite samples were used to represent the investigated sites. Each leachate was collected and chemically analyzed (Garrabrants et al. 2011) and the results shown in Table 2 were used in estimating leachate output.

\section{Data analysis}

Soil to plant element transfer factor (TF) was calculated as the ratio of element concentrations in plants and the corresponding concentrations in soil on dry weight basis. Daily intake of element (DI) was estimated according to the formula: $\mathrm{DI}=\mathrm{C}_{\text {element }} \times \mathrm{D}_{\text {food }}$ intake $/ \mathrm{B}_{\text {average weight }}$ where; $\mathrm{C}_{\text {element }}, \mathrm{D}_{\text {food intake, and }} \mathrm{B}_{\text {average }}$ weight represent the element concentrations in plants $(\mathrm{mg} / \mathrm{kg})$, daily intake of food $(\mathrm{kg})$ and average body weight $(\mathrm{kg})$, respectively. Health risk indices (HRIs) for intake of elements through the consumption of food crops were calculated using the following equations: $\mathrm{HRI}=\mathrm{DI} / \mathrm{RfD}$ where; HRI is the human risk index through the consumption, DI is the daily intake of element ( $\mathrm{mg}$ element/kg body weight/day) and $\mathrm{RfD}$ is the reference dose (WHO 2003).

\section{Mass balance}

The change in soil content of an element is the result of the net difference between input and output flows of that element. This can be mathematically expressed by the following equation: $\mathrm{G}_{\mathrm{t}}=\left(\mathrm{I}_{\mathrm{t}}-\mathrm{O}_{\mathrm{t}}\right)$ where; $\mathrm{G}$ is the change in total content of the soil, $\mathrm{I}$ is the integrated input and $\mathrm{O}$ is the overall output, all in $\left(\mathrm{g} \cdot \mathrm{ha}^{-1}\right)$ to a certain soil depth during a certain period of time $(\mathrm{t})$.

Input: Such change contribution to the soil bioavailable pool is highly depending on soil chemistry phenomena, considering the dynamic of the element in the soil system, the equation is $\mathrm{D}=(I-\mathrm{O})$ where $\mathrm{D}$ is the change in soil bioavailable content and $I$ represents the modified input rates. The input rates are related to the form in which the element is added, and to soil chemistry phenomena which determine the fate of the added element, thus the equation represents $I$ would be $I$ $=\mathrm{f}(\mathrm{I})$, any element concentration is the sum of sorbed amount to organic matter, clay, and primary minerals of the solid phase, and dissolved concentration in the soil solution; and since the distribution between solid and liquid phases in the soil is mainly controlled by surface adsorption-desorption reactions which are rapid and reversible so this function can be characterized by a thermodynamic equilibrium distribution such as Freundlich equation $\left(S=k_{f} \cdot C^{b}\right)$ where; $S$ is the sorbed concentration of the element in the solid phase. $\mathrm{k}_{\mathrm{f}}$ is the distribution coefficient in L. $\mathrm{kg}^{-1}$ and $\mathrm{b}$ is dimensionless and typically $\leq 1$ (Moolenaar 1997). For $b \approx 1$, the result is a linear sorption equation and as the adsorbed amount of the element in soil can be neglected if compared with the dissolved amount and assuming that all water content is soluble and mineral fertilizers content as well, the equations for their input rates - 
respectively- would be $I_{\mathrm{w}} \approx$ Irrigation water application rate $\left(\mathrm{m}^{3} \cdot \mathrm{ha}^{-1}\right)$. Element concentration in the applied irrigation water $\left(\mathrm{g} . \mathrm{m}^{3}\right)$ and $I_{\mathrm{f}} \approx$ Fertilizer application rate $\left(\mathrm{kg} \mathrm{ha}^{-1}\right)$. Element concentration in the applied fertilizer $\left(\mathrm{g} . \mathrm{kg}^{-1}\right)$. On the other hand, organic matter contribution to the soil bioavailable pool of an element is depending on its decomposition rate, therefore the equation for manure input rate could be $I_{\mathrm{m}} \approx$ Manure application rate $\left(\mathrm{kg} \cdot \mathrm{ha}^{-1}\right)$. Element concentration in the manure $\left(\mathrm{g} \cdot \mathrm{kg}^{-1}\right)$ . factor depends on decomposition rate. Janssen (1984) empirically determined a time-dependent factors for different organic materials, which were used in the calculations. Other sources (e.g. decompositions, rainfall, atmospheric depositions) of trace elements will be neglected in the calculations, because of its nonsignificance if compared with the agricultural usage during one growing season.

Output: The mass balance considers the amounts taken off the soil by the harvest and by leachate from the investigated layers, only plant parts which were harvested, the following equation was used to calculate output by plant: $\mathrm{O}_{\mathrm{h}}=\mathrm{C}_{\mathrm{p}}$. $\mathrm{Y}$ where; $\mathrm{C}_{\mathrm{p}}$ element concentration in plant part $(\mathrm{g} . \mathrm{kg}), \mathrm{Y}$ the yield of that plant part $\left({\left.\mathrm{kg} . h a^{-1}\right)}^{-1}\right.$ on dry weight basis. To estimate the output through leachate: $\mathrm{O}_{\mathrm{L}}=\mathrm{C}_{\mathrm{L}}$. $\mathrm{V}_{\mathrm{L}}$ where; $\mathrm{C}_{\mathrm{L}}$ element concentration in leachate $\left(\mathrm{g} \cdot \mathrm{m}^{3}\right), \mathrm{V}_{\mathrm{L}}$ leachate volume $\left(\mathrm{m}^{3}\right)$. Leachate volume was estimated using the empirical formula described by $\mathrm{Li}$ and Gua (2011), Q = $\left(\mathrm{C}_{1} \mathrm{~A}_{1}+\mathrm{C}_{2} \mathrm{~A}_{2}\right) \cdot \mathrm{I} \cdot 10^{-3}$ where; Q Landfill leachate volume $\left(\mathrm{m}^{3} / \mathrm{d}\right) ; \mathrm{A}_{1}$ Landfill operations area $\left(\mathrm{m}^{2}\right) ; \mathrm{A}_{2}$ Landfill cover area $\left(\mathrm{m}^{2}\right) ; \mathrm{C}_{1}$ Leaking landfill operation area coefficient $\left(\mathrm{m}^{2}\right) ; \mathrm{C}_{2}$ Coverage area landfill leaking coefficient; I The maximum annual or monthly precipitation at conversion value $(\mathrm{mm} / \mathrm{d})$.

In order to analyze the data, some default assumptions were chosen to be used after exploring the published literature regarding the required uncertainties. To estimate the potential hazard to human health through consumption of food crops grown in the area; we assumed that the intake of grains, bread, and other wheat-flour products vary from 2-4 servings/d to 8-10 servings/d, average of 4 was applied; intake of broad been seeds is 1-2 servings/d, only one serving per day was assumed; average body weight (bw) of adult is 70 $\mathrm{kg}$; one serving weight is $50 \mathrm{~g}$ (WHO 2003). Also, Regarding the mass balance investigation of the studied elements, in the study area, during one season; the following hypothetical settings were assumed: (1) Pedological factors influence on the soil enrichment of the elements is very slight, thus, decomposition of soil mineral components considers insignificant input source in comparison with agricultural use input; also, rainfall (average of $80 \mathrm{~mm} / \mathrm{year}$ ) and other atmospheric depositions contribution to the soil pool of the studied elements is too little to be included as an input source (FAO 1998). (2) Leaching test results can be applied so as to estimate the leachate characteristics, a leaching coefficient of 0.2 was used (Li and Guo 2011, Garrabrants et al. 2001). (3) Manure contribution to soil bioavailable pool of the elements is correlated to its total content and decomposition rate, factors of (0.020.18) were considered (Janssen 1984). Based on field observations, erosion risk was also eliminated from the output pathways.

\section{Computer simulation}

The anticipation of long-term results was performed using Monte Carlo simulation, or probability simulation, which is a technique used to assess the impact of uncertainty in forecasting models (Mooney 1997), using random combinations of parameter values based on the results of the previous investigated variables. The parameter variables were described by normal probability on the basis of the KolgomorovSmirnoff test results. The simulation was produced in a Microsoft ${ }^{\circledR}$ Excel spreadsheet. In order to derive stable responses of the predicted values, the number of simulations was 10000 . The model inputs are the range, average and standard deviation of the variables studied in the mass balance.

\section{RESULTS AND DISCUSSION}

\section{Baseline of the investigation}

The total and the DTPA-extractable contents of the investigated elements are shown in Tables 3 and 4.

The total content was found to be evenly distributed throughout soil surface and subsurface layers; whereas, the DTPA-extractable concentrations were found to be relatively higher, in cases of $\mathrm{Fe}, \mathrm{Mn}$ and $\mathrm{Cu}$, in the surface soil than their contents in the subsurface soil. Concentrations of $\mathrm{Zn}, \mathrm{Ni}$, Mo and $\mathrm{B}$ were evenly distributed among the surface and subsurface soil layers. Comparison between the soil content of the studied elements in different locations, taking into account the agricultural land use time, may indicate enrichment of the soil with the studied elements at some locations.

Concentrations of $\mathrm{Fe}, \mathrm{Mn}, \mathrm{Zn}, \mathrm{Mo}$ and $\mathrm{B}$ in irrigation water ranged between 0.11-0.26, 0.01-0.71, $0.01-0.06,0.003-0.018$, and $0.05-0.17$, respectively (Table 5). In 2006 the World Health Organization has published guidelines for the safe use of wastewater; the threshold levels of the studied elements for crop production are shown by the end of the table, these values are for water used on a continues basis at one site, with good irrigation practices i.e. $5000-1000 \mathrm{~m}^{3}$.ha ${ }^{1}$ per year. The concentrations of the investigated 


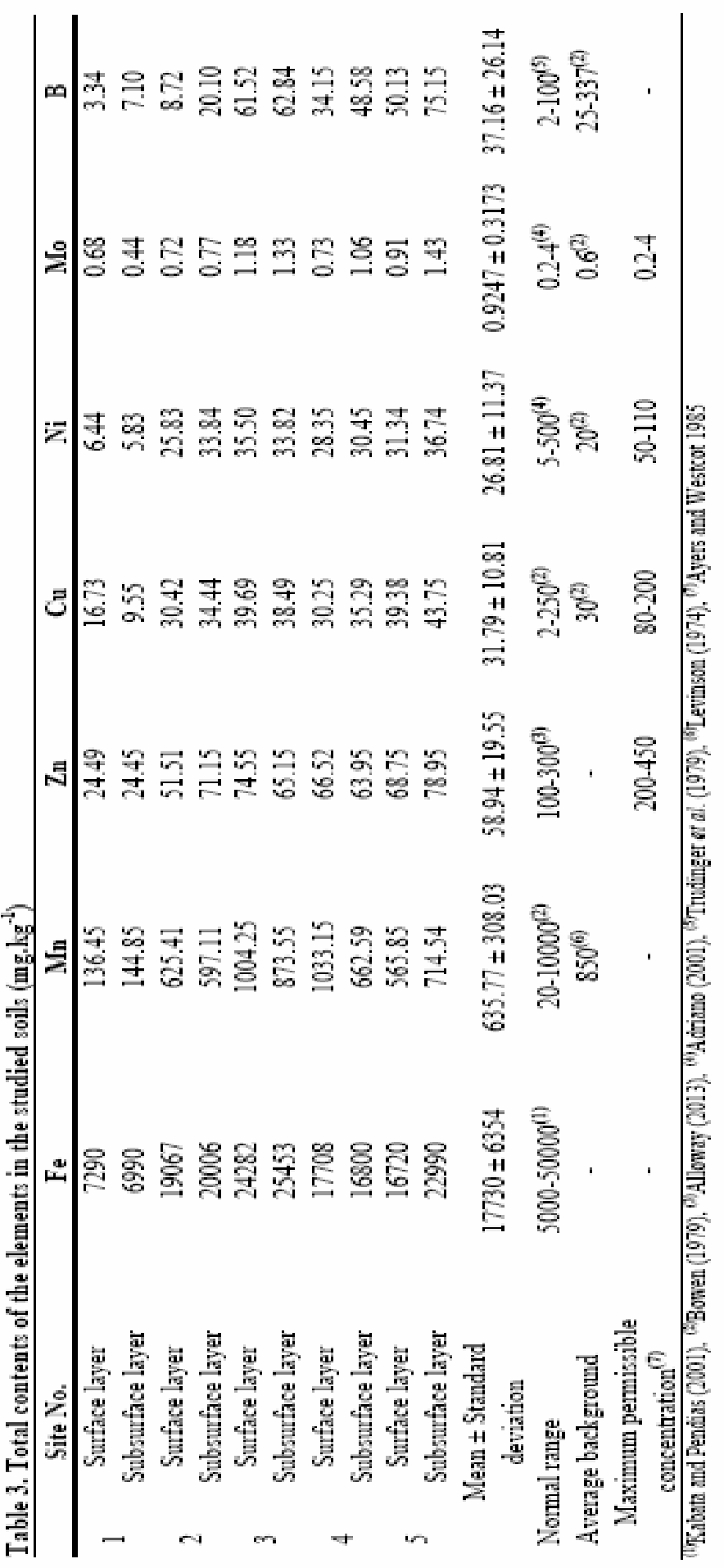




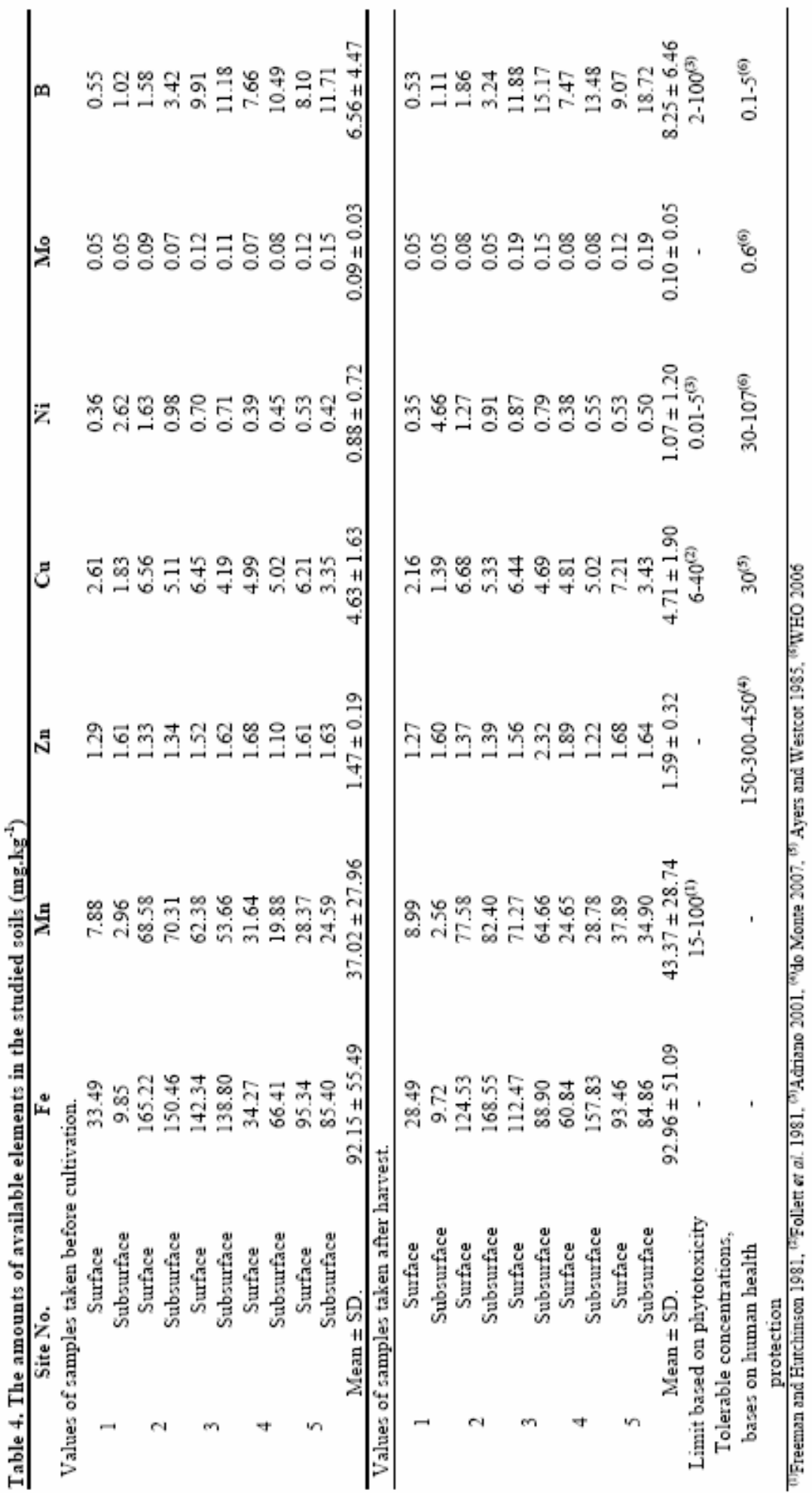


Table 5. Irrigation water content of the studied elements $\left(\mathrm{mg.L}^{-1}\right)$

\begin{tabular}{cccccccc}
\hline Site No. & Fe & Mn & Zn & Cu & Ni & Mo & B \\
\hline 1 & 0.02 & 0.02 & 0.02 & $<0.002$ & $<0.0005$ & 0.003 & 0.15 \\
2 & 0.02 & 0.01 & 0.02 & $<0.002$ & $<0.0005$ & 0.003 & 0.06 \\
3 & 0.01 & 0.01 & 0.06 & $<0.002$ & $<0.0005$ & 0.004 & 0.05 \\
4 & 0.26 & 0.71 & 0.01 & $<0.002$ & $<0.0005$ & 0.003 & 0.17 \\
5 & 0.11 & 0.44 & 0.02 & $<0.002$ & $<0.0005$ & 0.018 & 0.12 \\
$\begin{array}{c}\text { Recommended maximum } \\
\text { concentration }\end{array}{ }^{(1)}$ & $0.1-5$ & $0.2-1.5$ & 2 & 0.2 & 0.2 & 0.01 & $0.7-3$ \\
${ }^{(1)}$ WHO 2006 & & & & & & &
\end{tabular}

Table 6. Concentration of the studied elements in the applied fertilizers (mg.kg $\left.{ }^{-1}\right)$

\begin{tabular}{|c|c|c|c|c|c|c|c|c|c|}
\hline \multirow[t]{2}{*}{ Fertilizer } & \multirow[t]{2}{*}{$\mathbf{F e}$} & \multirow[t]{2}{*}{ Mn } & \multirow[t]{2}{*}{$\mathbf{Z n}$} & \multirow[t]{2}{*}{$\mathbf{C u}$} & \multirow[t]{2}{*}{$\mathbf{N i}$} & \multirow[t]{2}{*}{ Mo } & \multirow[t]{2}{*}{ B } & \multicolumn{2}{|c|}{$\begin{array}{c}\text { Application rate } \\
\text { kg.ha }^{-1}\end{array}$} \\
\hline & & & & & & & & Wheat & Broad bean \\
\hline Superphosphate & 6852 & 125.18 & 112.05 & 15.04 & 22.08 & 4.11 & 0.002 & 240 & 240 \\
\hline Potassium sulphate & 650 & 21.50 & 7.65 & 0.91 & 0.01 & 0.12 & 0.001 & & 120 \\
\hline Ammonium sulphate & 904 & 33.46 & 4.89 & 0.85 & 3.05 & 0.34 & 0.001 & & 240 \\
\hline Ammonium nitrate & 840 & 29.52 & 8.12 & 2.10 & 2.01 & 0.41 & 0.001 & 480 & \\
\hline Manure & 2040 & 302.25 & 204.17 & 93.10 & 14.80 & 4.42 & 39.80 & 15000 & 15000 \\
\hline $\begin{array}{c}\text { Permissible } \\
\text { concentration }^{(1)}\end{array}$ & - & - & $200-600$ & $80-200$ & $50-110$ & $4-20$ & 100 & & \\
\hline
\end{tabular}

Table 7. Plant contents of the studied elements (mg.kg $\left.{ }^{-1} \mathrm{D} . \mathrm{W}\right)$

\begin{tabular}{|c|c|c|c|c|c|c|c|c|c|}
\hline Harvest & $\begin{array}{l}\text { Site } \\
\text { No. }\end{array}$ & $\mathbf{F e}$ & Mn & Zn & $\mathrm{Cu}$ & $\mathbf{N i}$ & Mo & B & $\begin{array}{r}\text { Yield } \\
\mathrm{kg} \cdot \mathrm{ha}^{-1}\end{array}$ \\
\hline \multirow{5}{*}{$\begin{array}{l}\text { Wheat } \\
\text { grain }\end{array}$} & 1 & 303 & 44 & 19 & 6 & 1.6 & 2.0 & 1.6 & 4410 \\
\hline & 2 & 299 & 58 & 25 & 8 & 1.1 & 1.0 & 1.5 & 4301 \\
\hline & 3 & 395 & 82 & 15 & 10 & 1.4 & 5.1 & 1.8 & 3593 \\
\hline & 4 & 1053 & 99 & 21 & 8 & 3.1 & 1.0 & 4.6 & 4012 \\
\hline & 5 & 282 & 60 & 26 & 8 & 1.0 & 1.0 & 2.3 & 4197 \\
\hline \multirow{5}{*}{$\begin{array}{l}\text { Wheat } \\
\text { straw }\end{array}$} & 1 & 655 & 38 & 15 & 5 & 1.7 & 1.6 & 2.4 & 4820 \\
\hline & 2 & 875 & 84 & 117 & 9 & 5.5 & 2.6 & 13.2 & 4579 \\
\hline & 3 & 570 & 79 & 62 & 9 & 2.3 & 1.8 & 20.9 & 3615 \\
\hline & 4 & 984 & 213 & 15 & 6 & 2.2 & 3.0 & 65.1 & 4217 \\
\hline & 5 & 555 & 44 & 76 & 6 & 3.2 & 1.6 & 2.5 & 4579 \\
\hline \multirow{5}{*}{$\begin{array}{c}\text { Broad } \\
\text { bean seed }\end{array}$} & 1 & 738 & 23 & 45 & 20 & 3.4 & 10.4 & 9.8 & 1495 \\
\hline & 2 & 512 & 21 & 53 & 16 & 3.7 & 13.5 & 0.4 & 1484 \\
\hline & 3 & 1260 & 33 & 68 & 22 & 3.9 & 7.3 & 0.7 & 1391 \\
\hline & 4 & 1639 & 33 & 71 & 24 & 4.0 & 15.5 & 10.9 & 1418 \\
\hline & 5 & 922 & 24 & 68 & 18 & 2.9 & 6.5 & 0.7 & 1181 \\
\hline \multirow{5}{*}{$\begin{array}{l}\text { Broad } \\
\text { bean } \\
\text { straw }\end{array}$} & 1 & 863 & 40 & 23 & 17 & 2.8 & 2.1 & 3.0 & 1555 \\
\hline & 2 & 509 & 19 & 17 & 11 & 2.0 & 2.5 & 6.4 & 1499 \\
\hline & 3 & 707 & 44 & 22 & 33 & 2.5 & 8.6 & 16.2 & 1402 \\
\hline & 4 & 1507 & 66 & 27 & 19 & 4.8 & 1.0 & 17.4 & 1446 \\
\hline & 5 & 695 & 37 & 31 & 13 & 2.3 & 2.5 & 3.5 & 1196 \\
\hline
\end{tabular}

elements are still below the permissible levels except for Mn and Mo in sites No. 4 and 5. Accordingly, longterm use of such water might cause ecological risk when using for irrigation (Mohamed 2013).

Concentration of the elements in the mineral fertilizers and manure were all within the permissible limits (Table 6); yet, the excessive use of organic fertilizer under such arid climatic conditions, may lead to soil enrichment of potentially toxic trace elements (Moharem 2016).

Concentration of the studied elements in the different parts of the investigated plants and their yield are shown in Table 7. 
Table 8 revealed that TF of Fe was notably high at sites 1 and 4 where the soil available content was relatively low; the linear relationship can be observed by excluding the values from those sites. The influence of irrigation water on Fe uptake was clear at site 4, such correlation is also confirmed statistically (Table 9), where the correlation coefficient $(r)$ values ranged between 0.74 and 0.88 for the relation between water concentration and plant content of Fe. TF of Mn shows similar observation, where $\mathrm{Mn}$ soil to plant TF was highest at site 1 where the soil DTPA extractable Mn was low, whilst the significant relation was observed between water concentration and straw content of $\mathrm{Mn}$. $\mathrm{TF}$ of $\mathrm{Zn}$ suggests that plant species is in dominant position as its (TF) values and (r) values showed no significant relation, that also was the case for $\mathrm{Cu}, \mathrm{Ni}$, Mo and B. However, such results in addition to the large range of transfer factors reported in the literature (Cui et al. 2004) show that the concentration of an element in soil is not the only factor influencing its transfer, plant physiology and irrigation water quality must be considered.

The data in Tables 7 and 10 show that elements concentration in edible plant parts and the corresponding reference daily dose were within the safe limits. The values of Health risk index refer to potential accumulation to hazard levels for $\mathrm{Fe}, \mathrm{Mn}$ and Mo. Taking into account other exposure sources (e.g. water, other foods) adds Zinc and Nickel to this potential risk through consumption of such food, especially on longterm cases such as local farmers and their families. Iron is an essential element for most life on Earth, increased exposure to iron poses a risk only in some cases of heredity. Zinc, Copper and Nickel are among the current list of Priority Pollutants, according to USEPA. Nickel is carcinogenic, Manganese toxicity has been reported through dietary overexposure and is evidenced primarily in the central nervous system (WHO 2003).

\section{Simulation results}

Main addition sources and depletion ways of the studied elements through the investigated crop production processes are shown in Table 11, and presented in Figures 2, 3, 4, 5, 6, 7, and 8. During the investigated growing season. The predicted soil enrichment rates of the studied elements are summarized in terms of Statistics (Table 12).

Table 8. Soil to plant transfer factors (TF) of the studied elements

\begin{tabular}{|c|c|c|c|c|c|c|c|c|}
\hline Plant part & $\begin{array}{l}\text { Site } \\
\text { No. }\end{array}$ & $\mathbf{F e}$ & Mn & $\mathbf{Z n}$ & $\mathrm{Cu}$ & $\mathbf{N i}$ & Mo & B \\
\hline \multirow{5}{*}{ Wheat grain } & 1 & 14.0 & 8.0 & 13.3 & 2.9 & 1.1 & 38.1 & 2.0 \\
\hline & 2 & 1.9 & 0.8 & 18.8 & 1.3 & 0.8 & 12.8 & 0.6 \\
\hline & 3 & 2.8 & 1.4 & 9.8 & 1.9 & 1.9 & 44.7 & 0.2 \\
\hline & 4 & 20.9 & 3.8 & 14.9 & 1.5 & 7.3 & 13.2 & 0.5 \\
\hline & 5 & 3.1 & 2.3 & 15.9 & 1.7 & 2.1 & 7.6 & 0.2 \\
\hline \multirow{5}{*}{ Wheat straw } & 1 & 30.2 & 7.0 & 10.1 & 2.3 & 1.1 & 29.5 & 3.0 \\
\hline & 2 & 5.5 & 1.2 & 87.6 & 1.5 & 4.2 & 33.3 & 5.3 \\
\hline & 3 & 4.1 & 1.4 & 39.4 & 1.6 & 3.3 & 15.9 & 2.0 \\
\hline & 4 & 19.6 & 8.3 & 10.7 & 1.2 & 5.1 & 39.5 & 7.2 \\
\hline & 5 & 6.2 & 1.7 & 47.0 & 1.3 & 6.7 & 11.7 & 0.3 \\
\hline \multirow{5}{*}{$\begin{array}{c}\text { Broad bean } \\
\text { seed }\end{array}$} & 1 & 34.1 & 4.3 & 31.3 & 8.8 & 2.3 & 198.1 & 12.5 \\
\hline & 2 & 3.2 & 0.3 & 39.9 & 2.7 & 2.8 & 173.1 & 0.2 \\
\hline & 3 & 9.0 & 0.6 & 43.1 & 4.2 & 5.5 & 64.6 & 0.1 \\
\hline & 4 & 32.6 & 1.3 & 51.2 & 4.8 & 9.6 & 204.0 & 1.2 \\
\hline & 5 & 10.2 & 0.9 & 41.8 & 3.8 & 6.1 & 49.2 & 0.1 \\
\hline \multirow{5}{*}{$\begin{array}{c}\text { Broad bean } \\
\text { straw }\end{array}$} & 1 & 39.8 & 7.3 & 15.6 & 7.8 & 1.9 & 40.0 & 3.8 \\
\hline & 2 & 3.2 & 0.3 & 12.4 & 1.8 & 1.5 & 32.1 & 2.6 \\
\hline & 3 & 5.0 & 0.8 & 13.8 & 6.2 & 3.6 & 76.1 & 1.5 \\
\hline & 4 & 29.9 & 2.6 & 19.0 & 3.7 & 11.5 & 13.2 & 1.9 \\
\hline & 5 & 7.7 & 1.4 & 18.8 & 2.8 & 4.8 & 18.9 & 0.4 \\
\hline Range & & $1.8-39.8$ & $0.3-8.3$ & $9.8-87.6$ & $1.2-8.8$ & $0.8-11.5$ & $7.6-204.0$ & $0.1-12.5$ \\
\hline
\end{tabular}


Table 9. Statistical correlation between element contents in plants and its content in both, irrigation water and soil

\begin{tabular}{|c|c|c|c|c|c|c|c|c|}
\hline The investigated relation & $\begin{array}{l}\text { Statistical } \\
\text { parameter }\end{array}$ & $\mathbf{F e}$ & Mn & $\mathbf{Z n}$ & $\mathbf{C u}$ & $\mathbf{N i}$ & Mo & B \\
\hline \multirow{2}{*}{ Wheat grain content and water content } & $\mathrm{r}$ & 0.879 & 0.620 & -0.664 & - & - & -0.267 & 0.665 \\
\hline & $\mathrm{r}^{2}$ & 0.772 & 0.385 & 0.440 & - & - & 0.071 & 0.443 \\
\hline \multirow{2}{*}{$\begin{array}{l}\text { Total output by grain yield and total input } \\
\text { by water }\end{array}$} & $\mathrm{r}$ & 0.891 & 0.737 & -0.729 & - & - & -0.290 & 0.719 \\
\hline & $r^{2}$ & 0.793 & 0.543 & 0.531 & - & - & 0.084 & 0.518 \\
\hline \multirow{2}{*}{$\begin{array}{l}\text { Wheat grain content and soil DTPA } \\
\text { extractable }\end{array}$} & $\mathrm{r}$ & -0.355 & 0.213 & -0.173 & 0.640 & -0.374 & 0.243 & 0.471 \\
\hline & $r^{2}$ & 0.126 & 0.045 & 0.030 & 0.410 & 0.140 & 0.059 & 0.222 \\
\hline \multirow{2}{*}{ Wheat straw content and water content } & $\mathrm{r}$ & 0.553 & 0.704 & 0.154 & - & - & -0.468 & 0.397 \\
\hline & $\mathrm{r}^{2}$ & 0.306 & 0.495 & 0.024 & - & - & 0.219 & 0.158 \\
\hline \multirow{2}{*}{$\begin{array}{l}\text { Total output by wheat straw yield and total } \\
\text { input by water }\end{array}$} & $\mathrm{r}$ & 0.450 & 0.719 & 0.028 & - & - & -0.410 & 0.423 \\
\hline & $r^{2}$ & 0.202 & 0.516 & 0.001 & - & - & 0.168 & 0.179 \\
\hline \multirow{2}{*}{$\begin{array}{l}\text { Wheat straw content and soil DTPA } \\
\text { extractable }\end{array}$} & $\mathrm{r}$ & -0.074 & 0.039 & -0.029 & 0.783 & 0.237 & -0.332 & 0.397 \\
\hline & $r^{2}$ & 0.005 & 0.002 & 0.001 & 0.614 & 0.056 & 0.110 & 0.157 \\
\hline \multirow{2}{*}{ Bean seed content and water content } & $\mathrm{r}$ & 0.747 & 0.413 & 0.261 & - & - & -0.629 & 0.873 \\
\hline & $r^{2}$ & 0.559 & 0.171 & 0.068 & - & - & 0.396 & 0.762 \\
\hline \multirow{2}{*}{$\begin{array}{l}\text { Total output by seed yield and total input } \\
\text { by water }\end{array}$} & $\mathrm{r}$ & 0.711 & 0.246 & 0.241 & - & - & -0.704 & 0.865 \\
\hline & $r^{2}$ & 0.506 & 0.060 & 0.058 & - & - & 0.496 & 0.749 \\
\hline \multirow{2}{*}{$\begin{array}{l}\text { Bean seed content and soil DTPA } \\
\text { extractable }\end{array}$} & $\mathrm{r}$ & -0.269 & 0.003 & 0.421 & -0.051 & -0.039 & -0.698 & -0.263 \\
\hline & $r^{2}$ & 0.072 & 0.000 & 0.177 & 0.003 & 0.002 & 0.487 & 0.069 \\
\hline \multirow{2}{*}{ Bean straw content and water content } & $\mathrm{r}$ & 0.869 & 0.721 & -0.143 & - & - & -0.087 & -0.039 \\
\hline & $r^{2}$ & 0.755 & 0.520 & 0.021 & - & - & 0.008 & 0.001 \\
\hline \multirow{2}{*}{$\begin{array}{l}\text { Total output by bean straw yield and total } \\
\text { input by water }\end{array}$} & $\mathrm{r}$ & 0.869 & 0.721 & -0.143 & - & - & -0.087 & -0.039 \\
\hline & $r^{2}$ & 0.755 & 0.520 & 0.021 & - & - & 0.008 & 0.001 \\
\hline \multirow{2}{*}{$\begin{array}{l}\text { Bean straw content and soil DTPA } \\
\text { extractable }\end{array}$} & $\mathrm{r}$ & -0.645 & -0.477 & 0.633 & 0.048 & -0.462 & 0.458 & 0.602 \\
\hline & $r^{2}$ & 0.416 & 0.228 & 0.401 & 0.002 & 0.214 & 0.210 & 0.362 \\
\hline
\end{tabular}

Table 10. The selected criteria to estimate the health risk of consuming edible parts of the investigated crops

\begin{tabular}{|c|c|c|c|c|c|c|c|c|}
\hline \multicolumn{2}{|c|}{ Value description } & $\mathbf{F e}$ & Mn & $\mathbf{Z n}$ & $\mathbf{C u}$ & B & $\mathbf{N i}$ & Mo \\
\hline \multirow{2}{*}{$\begin{array}{l}\text { Wheat grain content } \\
\qquad\left(\mathrm{mg} \cdot \mathrm{kg}^{-1}\right)\end{array}$} & range & $282-1053$ & $43.5-99$ & $\begin{array}{l}15.4- \\
25.75\end{array}$ & $6.35-9.85$ & $1.5-4.6$ & $1-3.05$ & $1-5.05$ \\
\hline & mean & 466 & 68.6 & 21.25 & 7.85 & 2.36 & 1.61 & 2.01 \\
\hline \multirow{2}{*}{$\begin{array}{l}\text { Broad bean seed content } \\
\qquad\left(\mathrm{mg} \cdot \mathrm{kg}^{-1}\right)\end{array}$} & range & $512-1639$ & $20.5-33.1$ & $\begin{array}{l}45.3- \\
71.2\end{array}$ & $15.9-23.9$ & $0.4-10.9$ & $2.9-4$ & $6.5-15.5$ \\
\hline & mean & 1014 & 26.8 & 61.02 & 19.96 & 4.5 & 3.58 & 10.64 \\
\hline \multicolumn{2}{|c|}{ Limit in food ${ }^{(1)}\left(\mathrm{mg} \cdot \mathrm{kg}^{-1}\right)$} & 425 & 91 & 99.4 & 73.3 & - & 67 & - \\
\hline \multirow{2}{*}{$\begin{array}{l}\text { Wheat product's daily } \\
\text { intake }(\mathrm{mg} / \mathrm{kg} \mathrm{bw})\end{array}$} & range & $0.8-3.0$ & $0.12-0.28$ & $\begin{array}{c}0.04- \\
0.07\end{array}$ & $0.02-0.03$ & $\begin{array}{c}0.004- \\
0.013\end{array}$ & $\begin{array}{c}0.003- \\
0.009\end{array}$ & $\begin{array}{c}0.003- \\
0.014\end{array}$ \\
\hline & average & 1.3 & 0.196 & 0.061 & 0.022 & 0.007 & 0.005 & 0.006 \\
\hline \multirow{2}{*}{$\begin{array}{l}\text { Broad bean daily intake } \\
\qquad(\mathrm{mg} / \mathrm{kg} \text { bw })\end{array}$} & range & $0.37-1.17$ & $\begin{array}{c}0.015- \\
0.024\end{array}$ & $\begin{array}{c}0.03- \\
0.05\end{array}$ & $\begin{array}{c}0.011- \\
0.017\end{array}$ & $\begin{array}{c}0.0003- \\
0.0078\end{array}$ & $\begin{array}{c}0.002- \\
0.003\end{array}$ & $\begin{array}{c}0.005- \\
0.011\end{array}$ \\
\hline & average & 0.7 & 0.02 & 0.04 & 0.014 & 0.003 & 0.003 & 0.008 \\
\hline \multicolumn{2}{|c|}{ Reference dose $^{(1)}(\mathrm{mg} / \mathrm{kg}$ bw/day $)$} & 0.7 & 0.14 & 0.3 & 0.5 & 0.2 & 0.02 & 0.005 \\
\hline \multirow{2}{*}{$\begin{array}{l}\text { Health risk } \\
\quad \text { index }\end{array}$} & & 2.86 & 1.76 & 0.23 & 0.05 & 0.05 & 0.31 & 1.84 \\
\hline & bean & 1.03 & 0.14 & 0.15 & 0.03 & 0.02 & 0.13 & 1.52 \\
\hline
\end{tabular}

Joint FAO/WHO Expert Committee on Food Additives 2001 
Table 11. Major input sources and output pathways in the studied season $\left(\mathrm{g.ha}^{-1}\right)$

\begin{tabular}{|c|c|c|c|c|c|c|c|c|}
\hline \multicolumn{2}{|c|}{ Value description } & $\mathbf{F e}$ & Mn & Zn & $\mathbf{C u}$ & $\mathbf{N i}$ & Mo & B \\
\hline \multirow{2}{*}{$\begin{array}{c}\text { Irrigation } \\
\text { water, } \\
\text { input }\end{array}$} & Range & $99-1798$ & $88-4943$ & $74-418$ & - & - & $18-126$ & $336-1183$ \\
\hline & Average & 590 & 1661 & 182 & 7 & 1.75 & 43 & 749 \\
\hline \multicolumn{9}{|c|}{$\begin{array}{l}\text { Based on an application rate of } 7000 \mathrm{~m}^{3} \cdot \mathrm{ha}^{-1} \text {, and the data in Table } 5 \text {, where } 0.5 \mathrm{x} \text { detection limit was used to } \\
\text { calculate averages of } \mathrm{Cu} \text { and } \mathrm{Ni} \text {. }\end{array}$} \\
\hline \multirow{2}{*}{$\begin{array}{l}\text { Fertilizer, } \\
\text { input }\end{array}$} & Mineral & 1994 & 42 & 30 & 4 & 6 & 1 & 0 \\
\hline & Manure & 3045 & 1620 & 487 & 143 & 17 & 5 & 47 \\
\hline \multirow{4}{*}{$\begin{array}{c}\text { Wheat, } \\
\text { output } \\
\text { Broad } \\
\text { bean, } \\
\text { output }\end{array}$} & Range & $3480-8378$ & $375-1297$ & $146-644$ & $53-72$ & $13-30$ & $11-25$ & $18-292$ \\
\hline & Average & 5074 & 668 & 336 & 62 & 20 & 17 & 96 \\
\hline & Range & $1522-4504$ & $59-141$ & $103-139$ & $37-77$ & $6-13$ & $11-24$ & $5-41$ \\
\hline & Average & 2627 & 96 & 117 & 54 & 9 & 20 & 20 \\
\hline \multirow{2}{*}{$\begin{array}{l}\text { Leachate, } \\
\text { output }\end{array}$} & Range & $13-25$ & $15-38$ & $4-11$ & $3-6$ & $1-3$ & $2-10$ & $15-91$ \\
\hline & Average & 19 & 29 & 7 & 4.4 & 1.4 & 4 & 32 \\
\hline
\end{tabular}

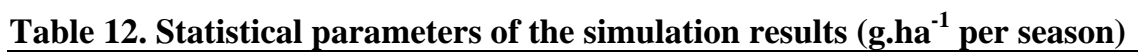

\begin{tabular}{cccccccc}
\hline Parameter & $\mathrm{Fe}$ & $\mathrm{Mn}$ & $\mathrm{Zn}$ & $\mathrm{Cu}$ & $\mathrm{Ni}$ & $\mathrm{Mo}$ & $\mathrm{B}$ \\
\hline Minimum & -4782 & -2605 & -152 & 20 & 26 & -100 & 42 \\
Maximum & 6771 & 8029 & 859 & 155 & 60 & 150 & 1369 \\
Mean & 556 & 2623 & 356 & 88 & 41 & 28 & 676 \\
Std Dev & 1489 & 1317 & 129 & 18 & 4 & 33 & 170 \\
\hline
\end{tabular}

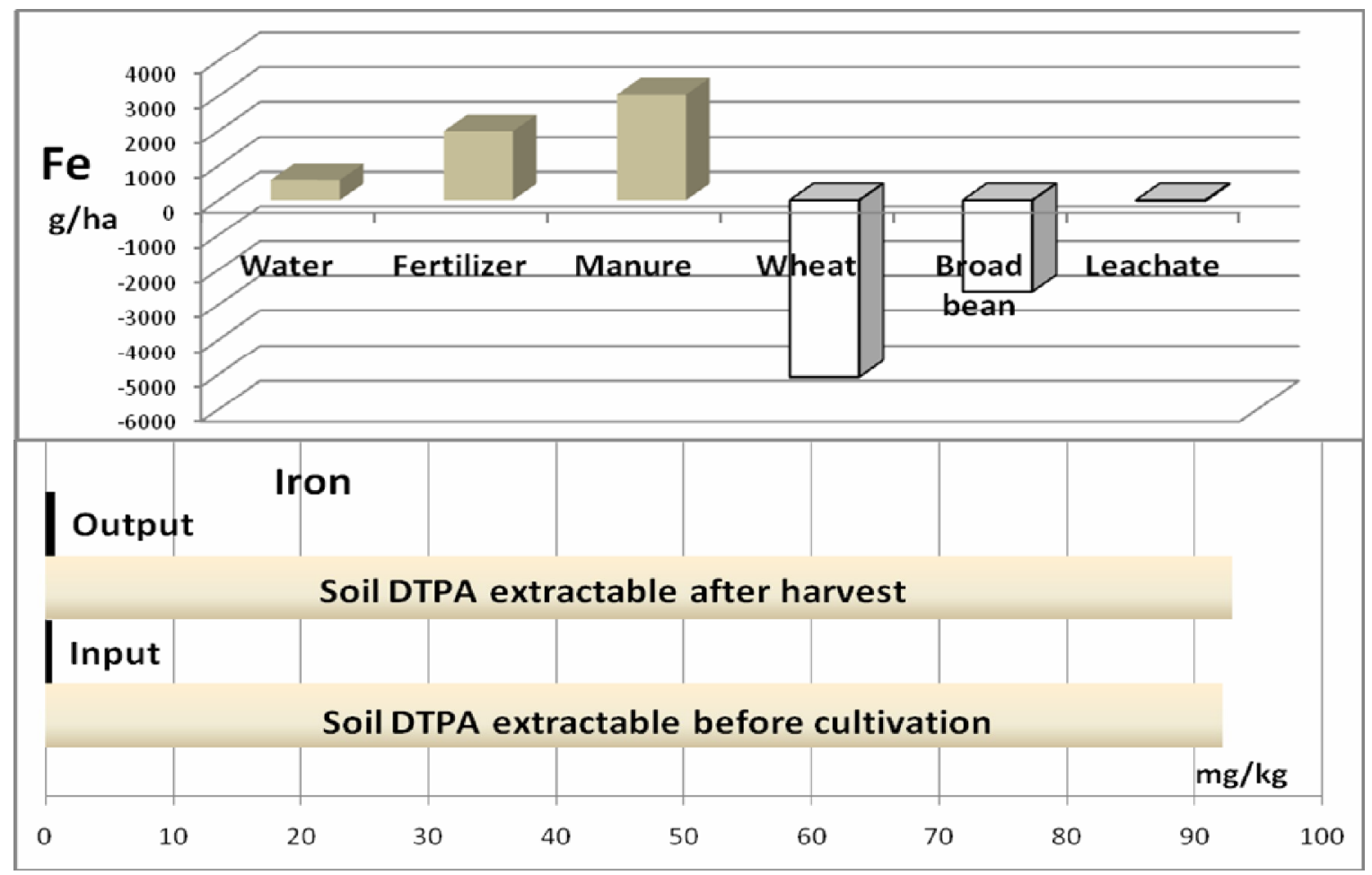

Fig. 2. Illustration of the mass balance of Iron 


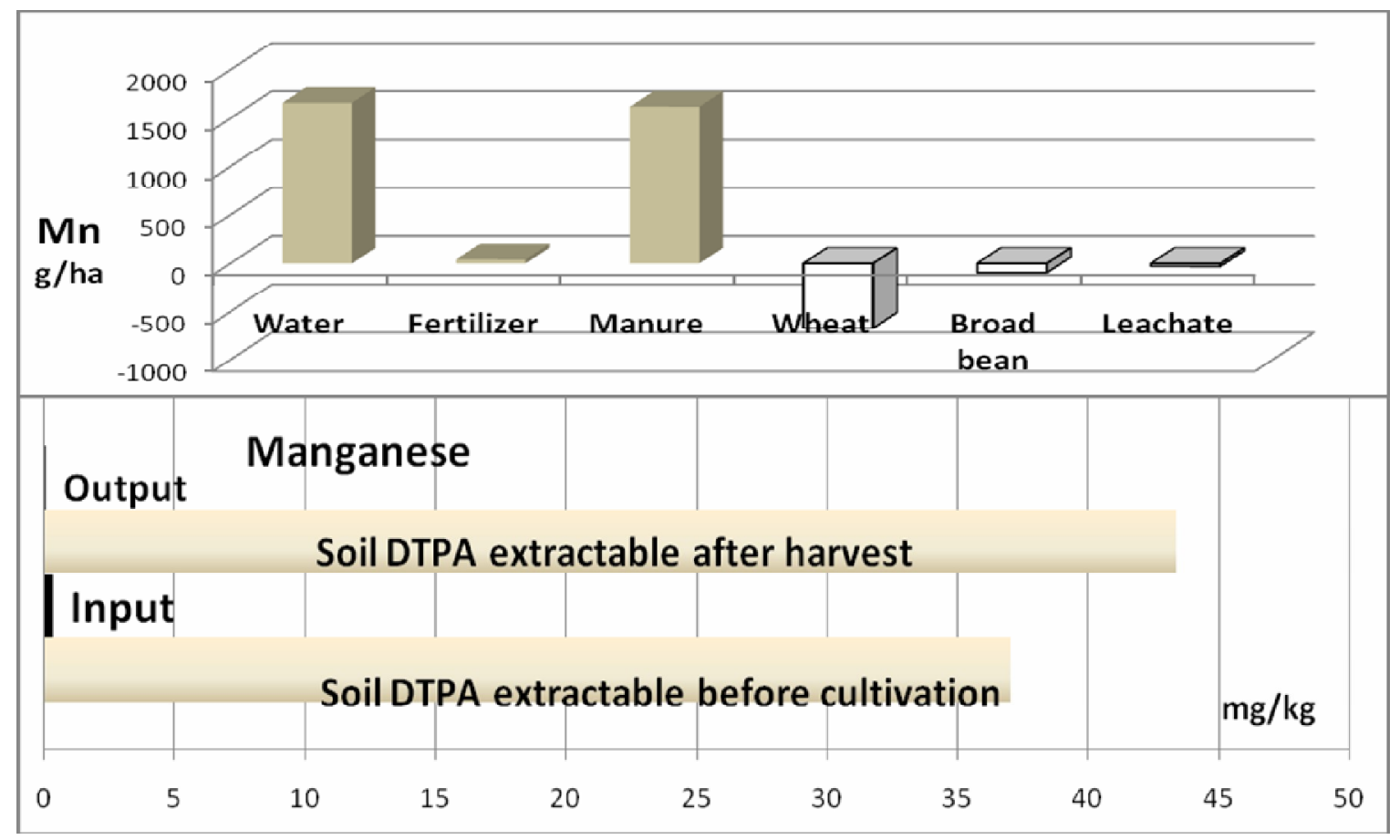

Fig. 3. Illustration of the mass balance of Manganese

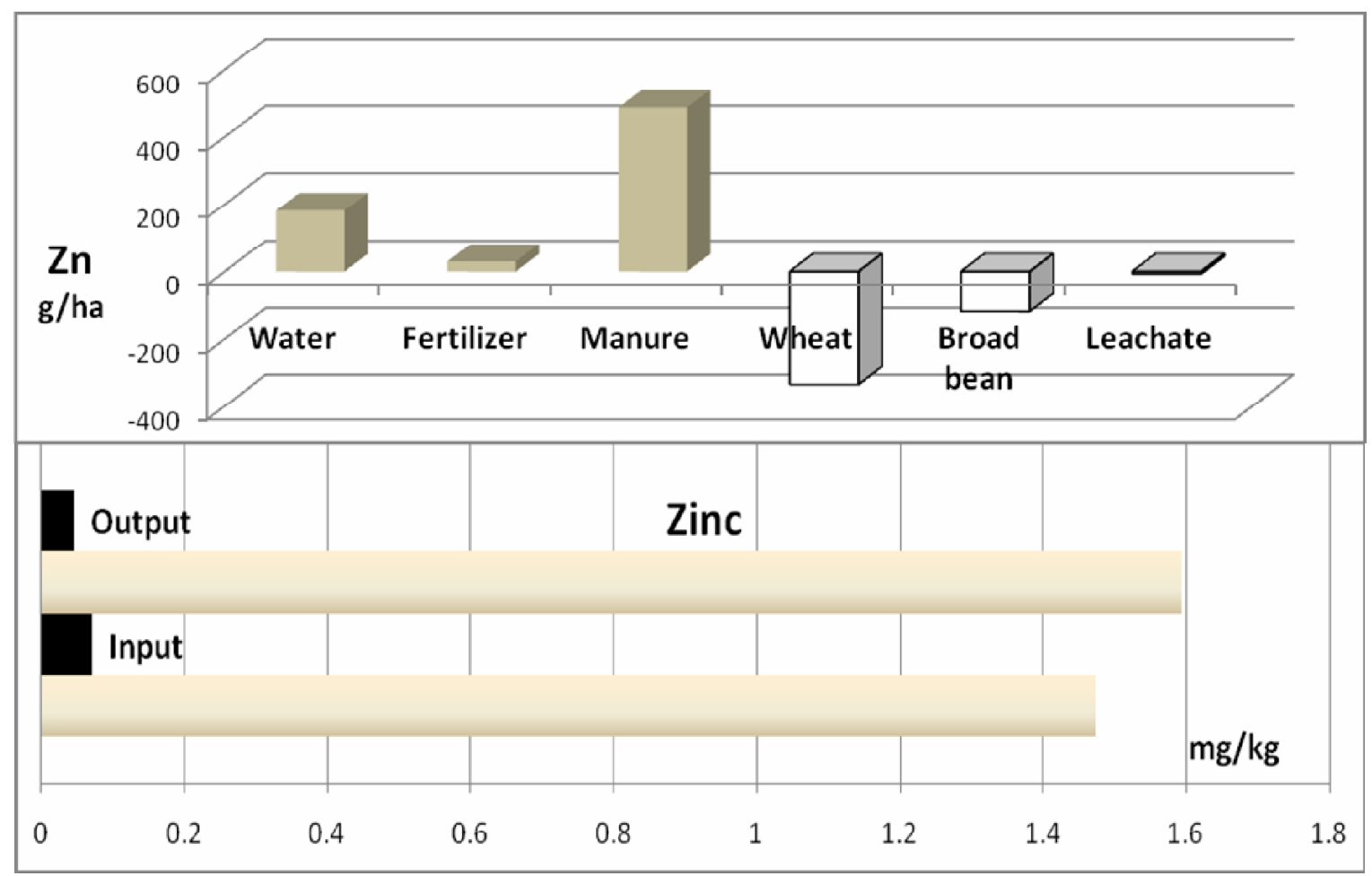

Fig. 4. Illustration of the mass balance of Zinc 


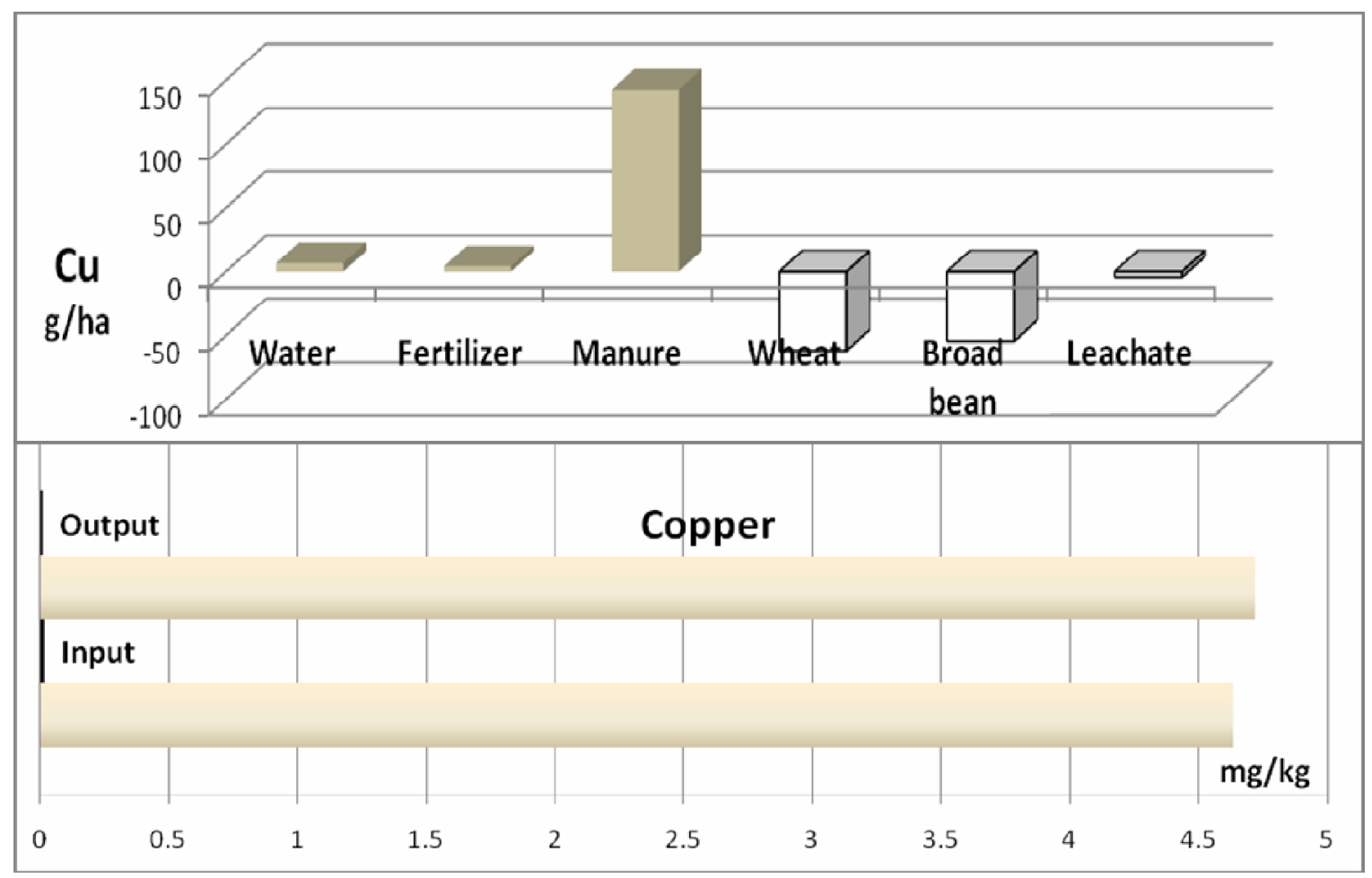

Fig. 5. Illustration of the mass balance of Copper

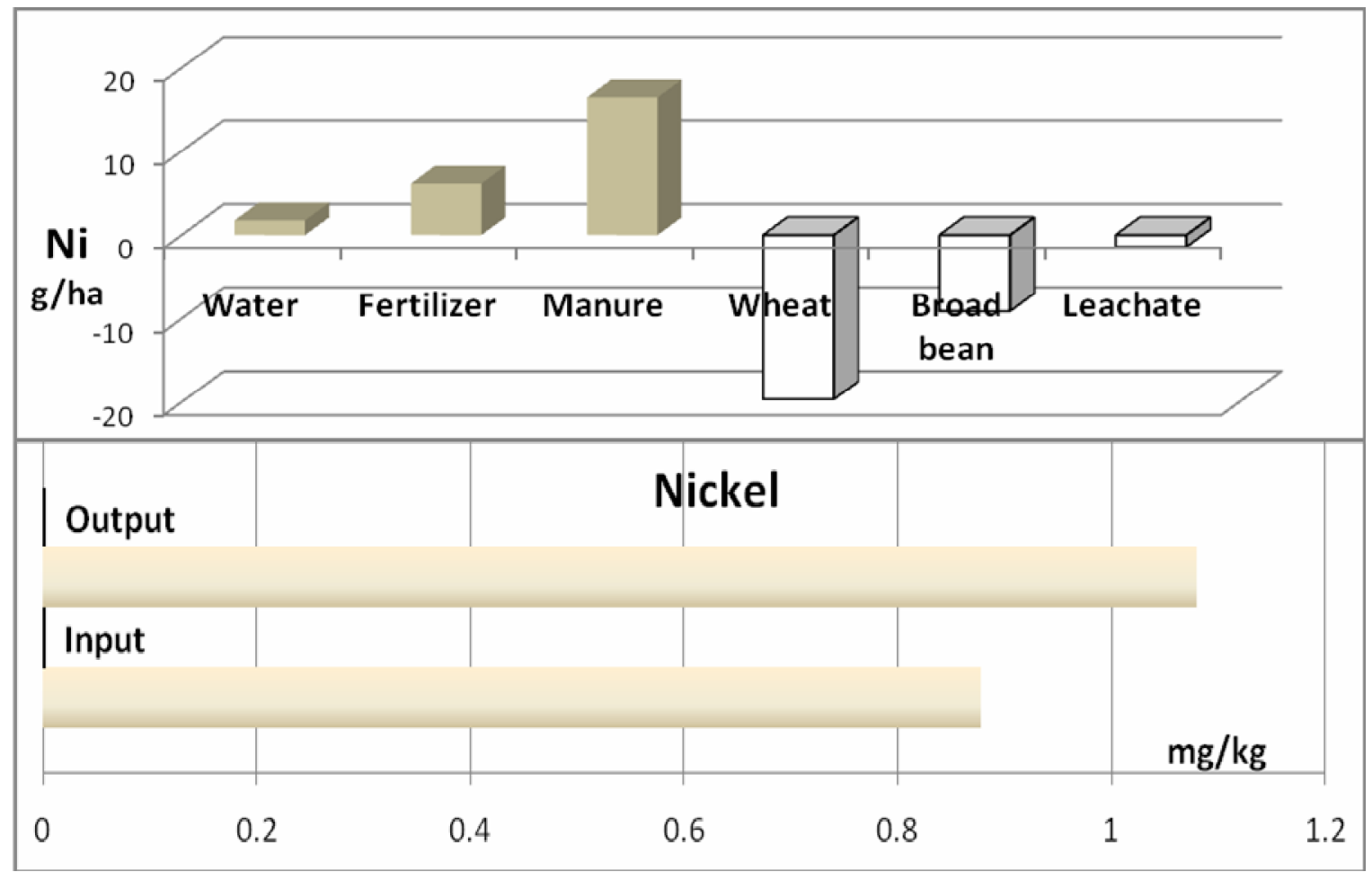

Fig. 6. Illustration of the mass balance of Nickel 


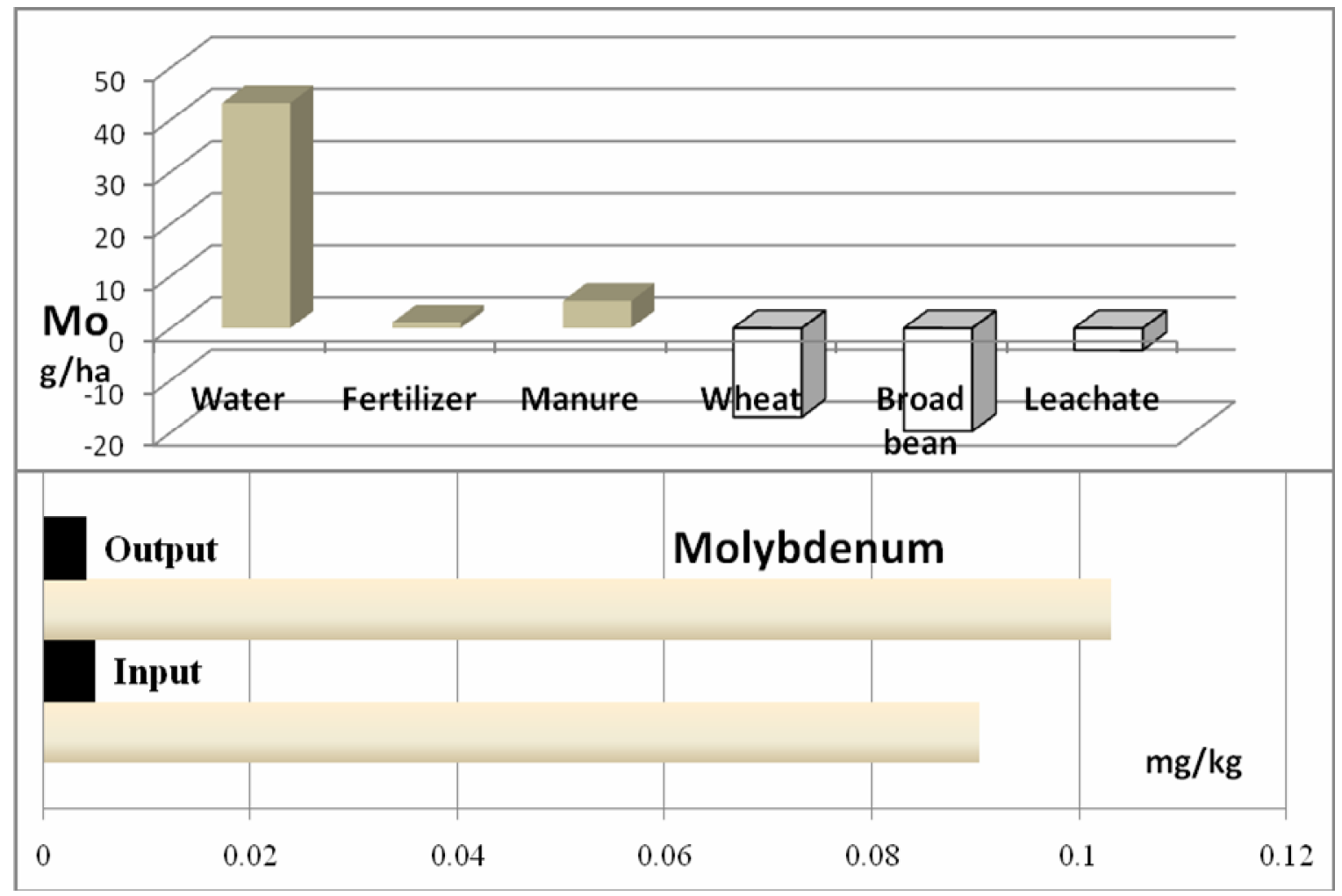

Fig. 7. Illustration of the mass balance of Molybdenum

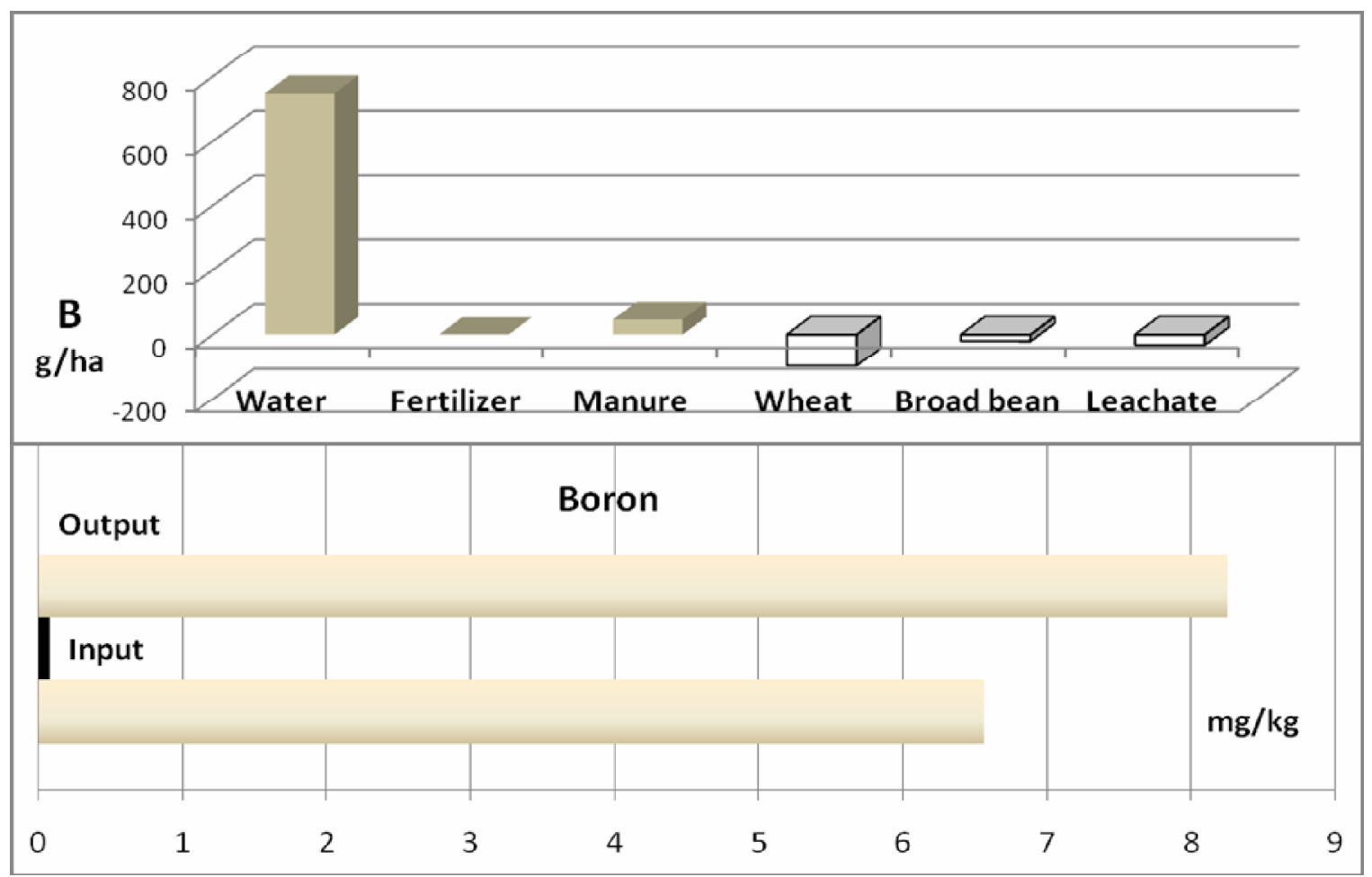

Fig. 8. Illustration of the mass balance of Boron 


\section{Iron}

The simulations show an enrichment probability of $65 \%$, the predicted $90^{\text {th }}$ percentile was 2458.57 g.ha $^{-1}$ per season (i.e. $90 \%$ of the results are less than 2458). Sensitivity analysis show that the prediction model for $\mathrm{Fe}$ status is significantly correlated to plant uptake followed by irrigation water content.

\section{Manganese}

The probability of $\mathrm{Mn}$ enrichment is $98 \%, 90^{\text {th }}$ percentile value was 4322 g.ha ${ }^{-1}$, with high sensitivity to irrigation water quality, followed by plant uptake then manure content of the element.

\section{Zinc}

The simulation of $\mathrm{Zn}$ input/output suggests a $100 \%$ enrichment probability. $90^{\text {th }}$ percentile is $524 \mathrm{~g}^{\mathrm{h}} \mathrm{ha}^{-1}, \mathrm{Zn}$ prediction model was found to be most sensitive to plant uptake and water content evenly.

\section{Copper}

Copper mass balance prediction model reveals a $100 \%$ enrichment probability. $90^{\text {th }}$ percentile value was 110 g.ha ${ }^{-1}$, sensitive to manure content then plant uptake.

\section{Nickel}

The simulation show a $100 \%$ probability of enrichment. $90^{\text {th }}$ percentile is 47 g.ha $^{-1}$, prediction is first correlated to mineral fertilizers content of the element, then irrigation water content.

\section{Molybdenum}

$80 \%$ enrichment probability was predicted, 70 g.ha ${ }^{-1}$ is the $90^{\text {th }}$ percentile seasonal enrichment rate, sensitive to irrigation water quality.

\section{Boron}

Boron mass balance simulation shows a $100 \%$ probability of enrichment. The predicted $90^{\text {th }}$ percentile was $892 \mathrm{~g} \mathrm{ha}^{-1}$, most sensitive to water content followed by plant uptake.

\section{CONCLUSION}

The study of trace elements flux through ecosystem components is necessary for successful ecological evaluation. Complexity of the system and the influence of soil chemistry, irrigation water quality, and plant species, lead to the importance of the site specific assessment including mass balance. Risk can be reduced through a better linking between the transfer processes and the dominant factors.

Analysis of the results showed the need to an interactive multi-criteria risk assessment framework in which considers all ecosystem components and the local conditions. The Monte Carlo simulations allowed the effects of parameter uncertainty to be estimated. The accumulation of the proper data would help to accrue modeling of the trace elements cycle in the ecosystem.

\section{REFERENCES}

Adriano, D.C. 2001. Trace elements in terrestrial environments: biogeochemistry, bioavailability, and risks of metals. $2^{\text {nd }}$ ed. Springer New York.

Alloway, B. J. 2013. Introduction. In Heavy metals in soils (pp. 3-9). Springer Netherlands.

APHA 2005. Standard Methods for The Examination of Water and Wastewater, $21^{\text {st }}$ ed. American Public Health Association, Washington, DC.

Avery, E.T. and H.E. Burkhart 1994. Forest Measurements. McGraw-Hill, Inc., New York, pp. 290.

Ayers, R. S., and D. W. Westcot, 1985. Water quality for agriculture (Vol. 29). Food and Agriculture Organization of the United Nations, Rome.

Bowen, H.J.M. 1979. Environmental Chemistry of the Elements. Academic Pr, New York.

Brinton, W. F. 2001. An international look at compost standard. Biocycle, 42. (4):74-6.

Bruinsma, J. (Ed.) 2003. World agriculture: towards 2015/2030: an FAO perspective. Earthscan.

do Monte, Maria 2007. Guidelines for good practice of water reuse for irrigation: Portuguese standard NP 4434. Wastewater Reuse-Risk Assessment, Decision-Making and Environmental Security :253-265.

Cui, Y. J., Y. G.Zhu, R. H.Zhai, D. Y. Chen, Y. Z Huang,., Y.Qiu and J. Z. Liang. 2004. Transfer of metals from soil to vegetables in an area near a smelter in Nanning, China. Environ. International. 30: 785-791.

El-Sisi, S. E. M. 2015. Status of soil chemical properties and nutrient contents of some crops cultivated of sahl el-tina north sinai under irrigation with low water quality of elsalam canal.Annals of Agric. Sci., Moshtohor ISSN 11100419.Vol. 53.(4):743-752.

FAO, 1998. World Reference Base for Soil Resources. Rep.84.Rome.

Filser, J., H. Koehler, A. Ruf, J. R?mbke, A. Prinzing and M. Schaefer 2008. Ecological theory meets soil ecotoxicology: Challenge and chance. Basic and Applied Ecology, 4(9), 346-355.

Follett, R.H., L.S. Murphy, and R.L. Donahue 1981. Fertilizers and Soil Amendments. Prentice-Hall, Englewood Cliffs, NJ.

Freedman, B., and T.C. Hutchinson. 1981. In N.W. Lepp, ed. Effeet of Heavy Metal Pollution in Plants, vol. 2: Metals in the Environment. Applied Science Publ, London.

Garrabrants, A. C., D. S. Kosson, H. A. van der Sloot, F. Sanchez, and O. Hjelmar. Background information for the Leaching environmental Assessment Framework (LEAF) 
test methods. U.S. Environmental Protection Agency, Washington, DC, EPA/600/R-10/170, 2011.

Gee, G.W. and J.W. Bauder. 1986. Particle Size Analysis.P.404-408. In A. Klute (ed.) Methods of Soil Analysis.Part 1.2nd ed. Agron. Monoger. No. 9 ASA and SSSA,Madison, WI.

Hafez A., M.Khedr, K.El-Katib, H.Gad Alla and S.Elmanharawy.2008. El-Salaam Canal project, Sinai II. Chemical water quality investigations, Desalination. 227.pp: 274-285.

Janssen, B. H. 1984. A simple method for calculating decomposition and accumulation of young soil organic matter. Plant and Soil. 76: 297-304.

Jarup, L. 2003. Hazards of heavy metal contamination. British medical bulletin. 68.(1):67-182.

Joint FAO/WHO Expert Committee on Food Additives. Meeting. (2001). Safety evaluation of certain mycotoxins in food (No. 74). Food \& Agriculture Org.

Kabata, A., and H. Pendias, 2001. Trace elements in soils and plants. CRC, Washington.

Kurniawan, T. A., G. Y. Chan, W. H.Lo and S. Babel. 2006. Physico-chemical treatment techniques for wastewater laden with heavy metals. Chemical Engineer. J. 118(1):83-98.

Levinson, A. A. 1974. Introduction to exploration geochemistry. Calgary: Applied Publishing.

Li, Y., and Guo, A. J. 2011. Amount of Leachate Generated Factors and Control Measures. In Advanced Materials Research.Vol. 250, pp:1667-1670. Trans Tech Publications.

Mico, C., L.Recatal?, M.Peris and J. S?nchez. 2006. Assessing heavy metal sources in agricultural soils of an European Mediterranean area by multivariate analysis. Chemosphere. 65: 863-872.

Minasny, B., A.B. McBratney, 2006. A conditioned Latin hypercube method for sampling in the presence of ancillary information. Computers \& Geosciences. 32:1378-1388.

Mohamed I. A. 2013.Irrigation water quality evaluation In ElSalam Canal Project. International J. Adv. Engineer. Sci. Applied Mathematics 3: 21-28.

Moharem, M. L. 2016. Solubility and availability of heavy metals in soils as affected by compost amendment. Alex. Sci. Exch. J, 37, 36-44.

Moolenaar, S. W., T. M.Lexmond, and S. E. van der Zee.1997. Calculating heavy metal accumulation in soil: a comparison of methods illustrated by a case-study on compost application. Agric. Ecosystems Environ. 66: 7182.

Mooney, C. Z. 1997. Monte carlo simulation (Vol. 116). Sage Publications.

Nicholson, F. A., S. R. Smith, B. J Alloway, C. CarltonSmith, and B. J. Chambers 2003. An inventory of heavy metals inputs to agricultural soils in England and Wales. Sci. Total Environ. 311: 205-219.

Page, A.L., R.H. Miller and D.R Keeney 1982. Methods of Soil Analysis, Part 2, Chemical and Microbiological Properties , 2nd ed., Agronomy Series No 9, Am. Soc. Agron., Madison, WI.

Pendergast, M. M., and E. M. Hoek 2011. A review of water treatment membrane nanotechnologies. Energy Environ. Sci., 4: 1946-1971.

Ragab, M. M., A. S. Antar, N. I. Talha and M. I El-Shahawy 2007. Factors Affecting Chemical DTPA-Extractability of Some Heavy Metals From Different Soil Types in Egypt. Alex. Sci. Ex., 28: 183-188.

Rickert, D. 1993. Water quality assessment to determine the nature and extent of water pollution by agriculture and related activities. In: Prevention of Water Pollution by Agriculture and Related Activities. Proceedings of the FAO Expert Consultation, Santiago, Chile, 20-23 October, 1992. Water Report 1. FAO. Rome. pp: 171-194.

Samia EL-Safy F. and El-Sayed S. M. 2008. Heavy Metals in Some Egyptian Foods. Alex. Sci. Ex, 29: 1-15.

Schnoor, J. L. 1996. Environmental modeling: fate and transport of pollutants in water, air, and soil. John Wiley and Sons.

Soltanpour, P.N. 1991. Determination of nutrient element availability and elemental toxicity by the AB-DTPA soil test and ICPS. Adv. Soil Sci. 16: 165-190.

Terry, N., and G. S. Banuelos (Eds.). 1999. Phytoremediation of contaminated soil and water. CRC Press.

Trudinger, P.A., D.1. Swaine, and G.W. Skyring. 1979. In P.A. Trudinger and D.l. Swaine, eds. Biogeochemical Cycling of Mineral-Forming Elements. Elsevie, Amsterdamr.

USEPA - United State Environmental Protection Agency; USEPA 3050B, Method 3050B. Acid Digestion of Sediments, Sludges and Soils, https://www.epa.gov/sites/production/files/201506/documents/epa-3050b.pdf, accessed April, 2016.

Van Deuren, J., T. Lloyd, S. Chhetry L., Raycharn, J. Peck, 2002. Remediation Technologies Screening Matrix and Reference Guide, Federal Remediation Technologies Roundtable, 4.

Varma, A. 1991. Handbook of Inductively Coupled Plasma Atomic Emission Spectroscopy. Boca Raton, FL: CRC, Inc.

Wolf B. 1982. A comprehensive system of leaf analyses and its use for diagnosing crop nutrient status. Commun. Soil Sci. Plant Anal., 13: 1035-1059.

WHO 2006. Guidelines for the Safe Use of Wastewater, Excreta and Greywater: Policy and regulatory aspects (Vol. 1). World Health Organization.

WHO 2003. Food based dietary guidelines in the WHO European

Region. http://www.euro.who.int/_data/assets/pdf_file/00 17/150083/E79832.pdf, accessed July, 2016. 


\section{الملخص العربي}

\section{تقييم حيوي بيئي لحالة بعض العناصر الاقيقة في شمال سيناء}

أسامة محمد عبد المطلب و شريف محمود إبر اهيم و شيرين شحاتة مريد

والأسمدة المستعملة خلال الموسم وكذلك المستتفذ بواسطة النبات و الرشح ونم تقدير القيم المرجعية للعناصر في منطقة

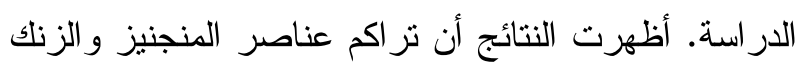
و النيكل و الموليبدنم و البورون في التربة كان نتيجة النشاط

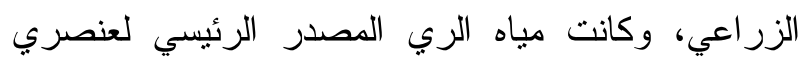

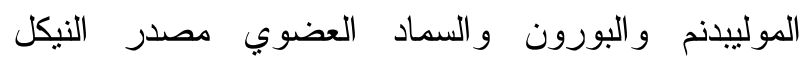

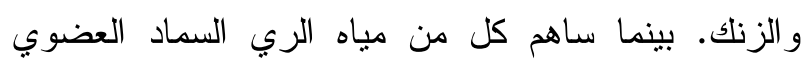

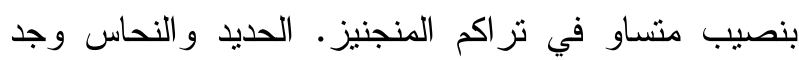

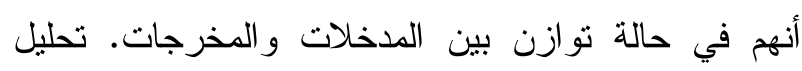

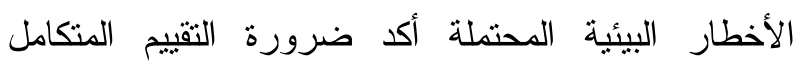
والحاجة إلى نظام رصد وأرقام مرجعية مناسبة للمنطقة وظروفها.
استعمال مياه منخفضة الجودة لري المحاصيل وفي ظل سوء الإدارة، يمثل خطر يزحف ببطء مهددا استمرارية

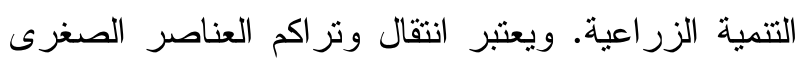

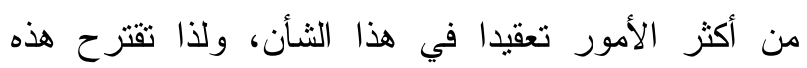
الدراسة نهج مبسط لرصد وتقييم الأخطار البيئية المحتملة

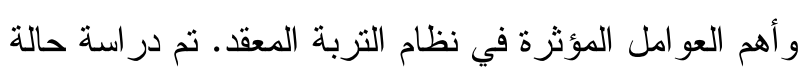

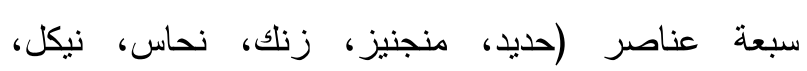

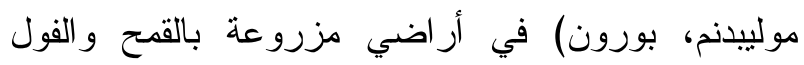
البلدي بمنطقة سهل الطينة - شمال سيناء، وتبع ذلك تقيبيم الأخطار المحتملة لكل عنصر باستخدام المقاييس المناسبة.

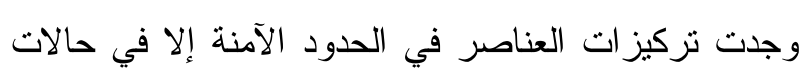
قليلة. تم تقدير المضاف من كل عنصر بواسطة مياه الري 